Author: KJ Selala

THE ENFORCEABILITY OF ILLEGAL EMPLOYMENT CONTRACTS ACCORDING TO

THE LABOUR APPEAL COURT: COMMENTS ON KYLIE V CCMA 20104 SA 383 (LAC)

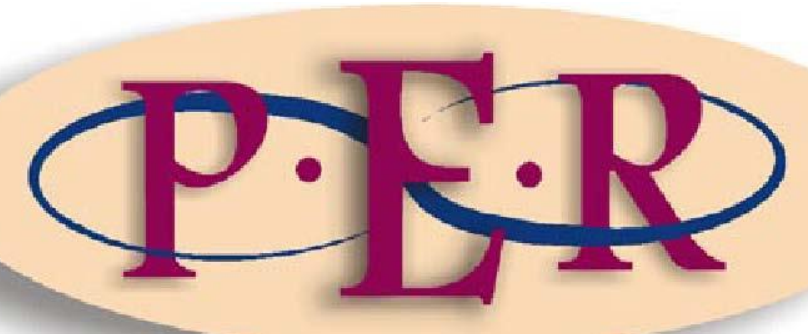

2011 VOLUME 14 No 2

DOI: 10.4314/pelj.v14i2.9 


\section{THE ENFORCEABILITY OF ILLEGAL EMPLOYMENT CONTRACTS ACCORDING TO THE LABOUR APPEAL COURT: COMMENTS ON KYLIE V CCMA 20104 SA 383 (LAC)}

\section{KJ Selala*}

On 28 May 2010, the Labour Appeal Court delivered a judgment in the case of Kylie $v C_{C C M A^{1}}$ regarding the jurisdiction of the CCMA to resolve a dispute of unfair dismissal involving a sex worker. Coincidentally, the judgment was handed down on the eve of the FIFA 2010 World Soccer competition, held in South Africa, ${ }^{2}$ when a large contingent of sex workers were reportedly expected to descend on the shores of the Republic to ply their trade during the tournament. ${ }^{3}$ Unsurprisingly, given the controversy attached to the issues, the judgment was well noted in the media and drew some quite interesting commentary in legal circles. ${ }^{4}$ In the judgment delivered by Davis JA, with which Zondo JP and Jappie JA concurred, the Court overturned a previous judgment of the Labour Court, ${ }^{5}$ where it was held that the CCMA ought to have refused to grant a relief to the employee because by doing so it would have been sanctioning or encouraging illegal activity. The Labour Appeal Court held that the CCMA did have the jurisdiction to resolve the dispute, regardless of the fact that sex work is an illegal activity. ${ }^{6}$ In justifying the conclusion it reached the court premised its argument on section 23(1) of the Constitution, ${ }^{7}$ which provides that everyone has a right to fair labour practices. The Court reasoned that the word "everyone" is a term of general import and unrestricted meaning and that it means what it conveys. ${ }^{8}$ Of the main issues examined by the Court was if a person such as a sex worker was entitled to enjoy constitutional rights in general, and specifically

Kobolo J Selala. Bluris LLB LLM (UNIN). Lecturer, Faculty of Law, North-West University, Mafikeng Campus (22013113@nwu.ac.za).

Kylie $v$ CCMA 20104 SA 383 (LAC).

The FIFA Soccer World Cup kicked off in Johannesburg on the $10^{\text {th }}$ of June 2010.

Le Roux 2010 www.mg.co.za; Kwinika 2010 nehandaradio.com; Skoch 2010 www.globalpost.com.

Le Roux 2010 www.mg.co.za.

Kylie v CCMA 200829 ILJ 1918 (LC).

Kylie v CCMA 20104 SA 383 (LAC) para 61.

Constitution of the Republic of South Africa, 1996 (hereafter the Constitution).

Kylie v CCMA 20104 SA 383 (LAC) para 17. 
those rights set out in section 23 of the Constitution. Relying on the minority judgment of O'Regan and Sachs $\mathrm{JJ}$ in $S v$ Jordan, ${ }^{9}$ the Court held that the illegal activity of a sex worker does not per se prevent the sex worker from enjoying a range of constitutional rights, including the right to fair labour practices.

The purpose of this case note is to analyse the judgment critically and to consider its implications for the future of labour litigation in South Africa. The correctness of the judgment, in particular, and especially insofar as it relates to the jurisdiction of the CCMA, or the Labour Court, to resolve disputes of the nature presented by the case, will be questioned. It will be argued that the Court erred in finding that the CCMA has the jurisdiction because jurisdiction is not only a question of interpretation but a matter of fact. It is either there or not. Jurisdiction, as will be shown, is predicated on the twin pillars of the court's authority over the litigating parties and the court's ability to grant an effective judgment. As the Constitutional Court has repeatedly stated, the courts are concerned with legality. ${ }^{10}$ And, to suggest that the requirement of legality in the determination of jurisdiction is unconstitutional, as the judgment implies, would no doubt be in conflict with the same Constitution that the courts seek to uphold. In this analysis, therefore, the main question will be this: should the Constitution, as the supreme law, be interpreted as conferring on the courts and tribunals jurisdiction to enforce any transactions which are in conflict with the law? Inevitably, the Courts' approach to the main issues raised by the appeal will be critically examined. Consequently, it will be argued that both the CCMA and the Labour Court's decisions were correct insofar as the jurisdictional ruling on the matter was concerned.

\section{$2 \quad$ Factual background}

The appellant, a certain Ms Kylie, (hereinafter the employee) was employed in a massage parlour as a sex worker. Her employment was terminated without a proper hearing. She then referred a dispute of unfair dismissal to the CCMA for arbitration. In the light of the fact that the employee was a sex worker, the CCMA Commissioner ruled that she did not have jurisdiction to entertain the dispute because sex work is

$S v$ Jordan 20026 SA 642 (CC).

$S$ v Jordan 20026 SA 642 (CC) para 30. 
strictly prohibited by legislation. ${ }^{11}$ The Commissioner argued that section 23 of the Constitution and the Labour Relations Act $^{12}$ (hereinafter the LRA) did not apply to workers who did not have a valid and enforceable contract, which was the situation in this instance, as the employee was engaged in an invalid contract. This decision of the Commissioner was then taken on review to the Labour Court.

In the Labour Court, ${ }^{13}$ the employee's argument was that the Commissioner committed a legal error in excluding workers who did not have a valid and therefore enforceable contract from the ambit of the LRA, because the LRA defines employees to include anyone 'who works for another person' and accordingly the Act applies to all employment relationships irrespective of whether they are underpinned by enforceable contracts or not. ${ }^{14}$ In the light of the approach taken in argument, the Labour Court sought to clarify at the outset what its judgment was about and which issues it does not decide. The Labour Court stated that its judgment does not decide (1) that a sex worker is an employee for the purposes of the LRA, just that neither the CCMA nor the Court should enforce the statutory right to a fair dismissal under the LRA; (2) that a sex worker is not entitled to protection under the Basic Conditions of Employment Act, occupational health legislation, workers' compensation or unemployment insurance and; (3) the issue as to whether or not the definition of employee in the LRA applies to those in an employment relationship without a valid contract. ${ }^{15}$ In the Court's opinion, the proper approach to the issues would not be to ask whether a sex worker was an employee within the ambit of the definition in the LRA or not. The correct approach, as the Court determined, would be to ask whether as a matter of public policy courts (and tribunals), by their actions, ought to sanction or encourage illegal conduct in the context of statutory and constitutional rights. ${ }^{16} \mathrm{It}$ is submitted that this approach was correct. Consequently, the Labour Court found that the CCMA Commissioner ought to have refused to grant the relief sought by the employee because by doing so the CCMA would have been sanctioning or

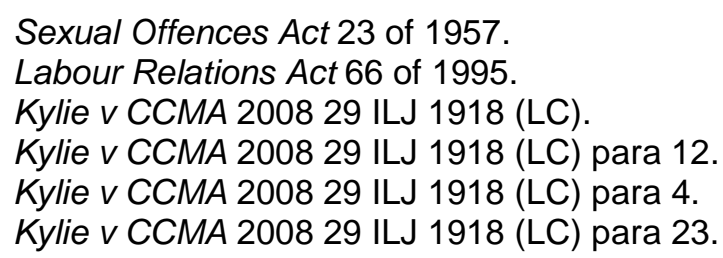


encouraging prohibited commercial sex. ${ }^{17}$ In effect, the Labour Court's judgment confirmed the CCMA's jurisdictional ruling on the matter. It is this decision of the Labour Court which gave rise to the judgment of the Labour Appeal Court under discussion.

\section{The decision of the Labour Appeal Court}

Two main issues stood out for the determination by the Court. Firstly, the Court had to determine whether or not the CCMA Commissioner was correct in her jurisdictional ruling, and/or whether or not the Labour Court was correct in its approach and assessment of the law and consequently its judgment. Secondly, and depending on its finding against the judgment of the Labour Court, if a remedy avails to an employee involved in the kind of the employment relationship presented by the case.

The Court commenced with an analysis of the Labour Court judgment. It noted that while the Labour Court conceded that Kylie was an employee for the purposes of the LRA, the Labour Court did not acknowledge her rights to relief or the enforceability of her rights in terms of the LRA simply because she was a sex worker and therefore, in the opinion of the Labour Court, not entitled to protection against unfair dismissal. ${ }^{18}$ On the other hand, the Court also noted the submissions made on behalf of the employee. According to the employee, the Labour Court adopted a wrong approach in its judgment. Instead of commencing with the Constitution, that is, whether or not a person such as the employee enjoyed constitutional rights in general and specifically those entrenched in section $23(1),{ }^{19}$ the Labour Court, so it was submitted, started with the discussion on policy as divined from the law of contract. $^{20}$ Further to that, the employee argued that it should be only after the question of the application of the Constitution has been answered, and if in the favour of the employee, that the Court would be required to proceed to determine the

17 Kylie v CCMA 200829 ILJ 1918 (LC) para 93. Although the Court's approach to the matter was different from the CCMA's, its decision nevertheless vindicated the position of the CCMA Commissioner regarding its jurisdictional ruling. In this case note it is contended that both the CCMA and the Labour Court's decisions were correct.

Kylie v CCMA 20104 SA 383 (LAC) para 3.

Section 23(1) of the Constitution provides that everyone has the right to fair labour practices.

Kylie v CCMA 20104 SA 383 (LAC) para 14. 
issues of remedy, and that it would be at this stage that the question of policy would come in. ${ }^{21}$ This submission, seemingly, impressed the Court. The Court stated that since the dispute was predicated on the application of the LRA, it would be necessary to commence with the Constitution, to examine the application of section 23(1) to the facts of the dispute. ${ }^{22}$ In its analysis the Court noted that section 23(1) provides everyone the right to fair labour practices and that the word 'everyone' is a term of general import and unrestricted meaning - it means what it conveys. ${ }^{23}$ The Court then made reference to the minority judgment of the Constitutional Court in $S v$ Jordan. ${ }^{24}$ In the latter case O'Regan and Sachs JJs had held that prostitutes are not stripped of rights to be treated with dignity simply because the nature of the work they undertake devalues the respect that the Constitution regards as inherent in the human body. ${ }^{25}$ The Court then turned to confront the key question, that is, whether section 23 affords protection to a sex worker. In its judgment the court found that it does. In support of this conclusion reference was made to a few cases, among others, NEHAWU $v \cup \mathrm{UCT}^{26}$; SANDU $v$ Minister of Defence ${ }^{27}$; State Information Technology Agency (Pty) Limited v CCMA ${ }^{28}$; and Denel (Pty) Ltd v Gerber. ${ }^{29}$

With reference to NEHAWU $v$ UCT the Court observed the Constitutional Court's emphasis that the focus of section $23(1)$ of the Constitution was on the relationship between the worker and the employer and the continuation of that relationship on terms that are fair to both. ${ }^{30}$ The Court further noted that in SANDU $v$ Minister of Defence the Constitutional Court considered the question as to whether members of the armed forces constituted workers for the purposes of section $23(2)^{31}$ of the Constitution. With reference to the latter case the Labour Appeal Court found that even if a person is not employed under a contract of employment, that does not deny

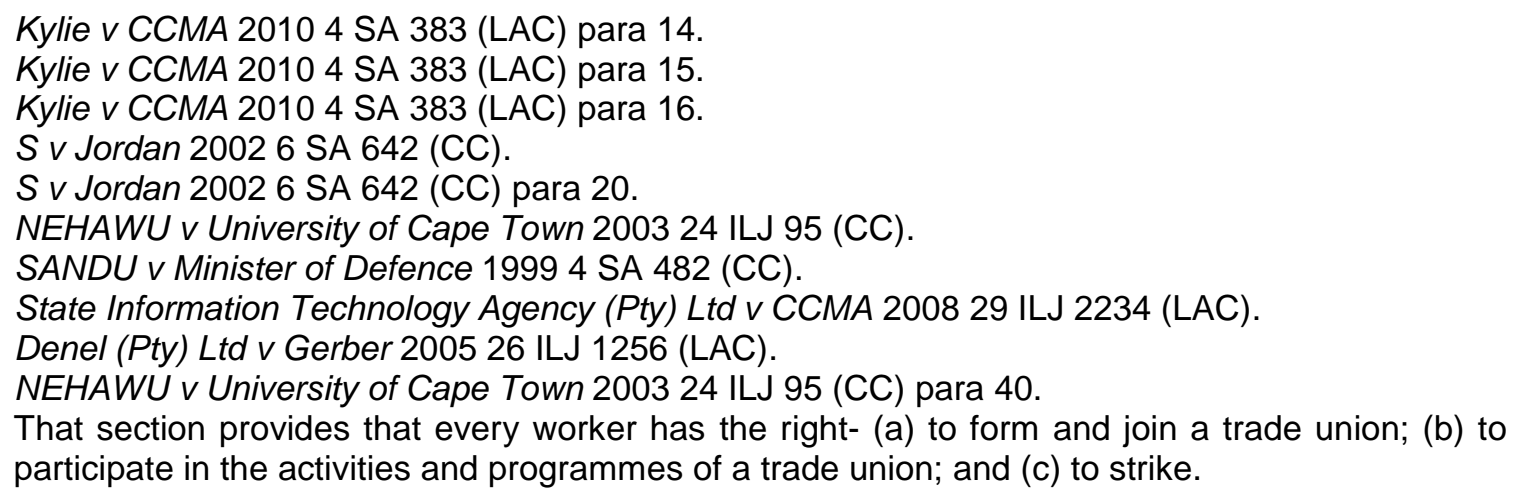
participate in the activities and programmes of a trade union; and (c) to strike. 
the employee all constitutional protection. ${ }^{32}$ Based on the State Information Technology (Pty) Limited $v$ CCMA and the Denel (Pty) Ltd $v$ Gerber cases, the court summarised its approach thus:

\begin{abstract}
In summary, as sex workers cannot be stripped of the right to be treated with dignity by their clients, it must follow that, in their other relationship namely with their employers, the same protection should hold. Once it is recognised that they must be treated with dignity not only by their customers but by their employers, section 23 of the Constitution, which, at its core, protects the dignity of those in an employment relationship should also be of application. ${ }^{33}$
\end{abstract}

Having decided that the sex worker meets the threshold requirement for constitutional protection, that is, being the beneficiary of the applicable constitutional rights, ${ }^{34}$ the Court turned to examine the question of relief. The Court noted that compensation for a substantively unfair dismissal would be inappropriate in the present kind of case. By contrast, however, the Court held that monetary compensation for a procedurally unfair dismissal would appear to be applicable in the appropriate case where the services rendered by the employee are classified as illegal. For this, the Court reasoned that this kind of compensation is independent of the loss of illegal employment and is treated as a solatium for the loss by an employee of her right to a fair procedure. ${ }^{35}$ Regarding the future application of the LRA to cases of a similar nature the Court stated that for the reasons given in its judgment, cases involving employment relationships which are in breach of legislation, such as the present dispute, should proceed through the constitutional threshold but not all will enjoy the defining weight of public policy so as to justify the granting of a remedy. ${ }^{36}$

SANDU v Minister of Defence 19994 SA 482 (CC) para 21.

Kylie v CCMA 20104 SA 383 (LAC) para 26.

Kylie v CCMA 20104 SA 383 (LAC) paras 21-28.

Kylie v CCMA 20104 SA 383 (LAC) para 53.

Kylie v CCMA 20104 SA 383 (LAC) para 57. 


\section{$4 \quad$ Analysis of and comment on Kylie v CCMA 20104 SA 383 (LAC)}

\subsection{The Court's approach to the issues}

The judgment, in my opinion, is problematic and quite erroneous on various levels. First, it is not readily ascertainable from the judgment what the main issues are. In its judgment the Court commenced with the background on the facts of the case, the submissions made by the parties both in the CCMA and the Labour Court, and the analysis of the Labour Court's judgment. ${ }^{37}$ Since the matter was an appeal against the decision of the Labour Court regarding its jurisdictional ruling, it was expected of the Labour Appeal Court to introduce, right at the beginning of its judgment, the main issues and the legal questions to be decided. Instead, the Labour Appeal Court cluttered the issue of jurisdiction with the question of the sex worker's entitlement to constitutional rights, such that the latter consideration overshadowed the main issue, which is jurisdiction. It is submitted that this approach contributed immensely to the Court's losing focus on what the main issue for determination in the appeal was. ${ }^{38}$

Secondly, the approach of the Court on the question of jurisdiction is, with respect, erroneous. As will be argued here below, instead of placing a heavy reliance on the rights of the person as an employee, the Court should have considered equally the nature of the dispute and the circumstances surrounding it to determine whether or not the dispute was enforceable in the courts. Linked to the Court's approach to the case is the order granted. The Court's order, it is submitted, is confusing and to some extent impracticable. An extensive argument in support of this contention is made below.

It is important to emphasise that this case hinged predominantly on jurisdiction, hence the order granted by the Court. In its approach, the Court preferred to decide the issues from the constitutional rights perspective. What the Court seemingly failed to do, though, was to put the dispute in a clearer perspective from the onset. Nevertheless, the Court proceeded on the basis that section 23 of the Constitution

Kylie v CCMA 20104 SA 383 (LAC) paras 1-15.

There is absolutely no doubt that the main issue before the Court was jurisdiction. The other aspect, namely the protection of the constitutional rights, was simply an ancillary matter. 
was the premise from which all issues related to the dispute could be addressed. In this regard the Court stated that 'since the dispute was predicated on the application of the LRA, it is necessary to commence with the source of the LRA, that is, to engage in an examination the application of section $23(1)$ to the present dispute'. ${ }^{39}$ The Court accepted that the word "everyone" in section 23(1) of the Constitution is a term of general import and unrestricted meaning, and that it conveys what it means. ${ }^{40}$ In the Court's reasoning, it would not matter if the employee was a criminal or involved in any other form of criminal activity as employment: the right to fair labour practice is available to everyone including a sex worker.

This reasoning of the Court seems attractive but cannot be accepted entirely without qualification. As a matter of logical construction, it is submitted, the right to fair labour practices is not available to "everyone" in the strictest literal sense, but applies exclusively to those persons who are involved in an employment relationship. ${ }^{41}$ It is distinct from other rights such as the right to life, the right to dignity, and the right to equality, all of which depend for their existence simply on the fact of one's being human. The latter rights are actually fundamental human rights which accord to every human being by reason of being alive. In contrast, the right to fair labour practices is available only to persons who are involved in an employment relationship. It is submitted that the Court's extensive examination of this concept was unnecessary because the status of the employee was not an issue in dispute in this case. All that was required or expected of the Court was to confirm, as the Court correctly did, that the employee was an employee for the purposes of the LRA and the Constitution. ${ }^{42}$ Surprisingly, the Court then proceeded to determine if the employee was entitled to relief. ${ }^{43}$

It is submitted, with respect, that this was a step prematurely taken by the Court. Instead of proceeding to consider the question of relief, the Court should have proceeded to consider the nature of the employment contract or relationship to

Kylie v CCMA 20104 SA 383 (LAC) para 15.

Kylie v CCMA 20104 SA 383 (LAC) para 16.

NEHAWU v University of Cape Town 200324 ILJ 95 (CC) para 40; SANDU v Minister of Defence 19994 SA 482 (CC) 481 para 22; Hannah v Government of the Republic of Namibia 20004 SA 940 (NmLC).

Kylie v CCMA 20104 SA 383 (LAC) para 28.

Kylie v CCMA 20104 SA 383 (LAC) para 28. 
determine whether or not it was legally enforceable. That examination, it is argued, was meticulously done by Cheadle $\mathrm{J}$ in the Labour Court. ${ }^{44}$ As will be shown below, it is not only the Court's power to hear a party that determines jurisdiction but most importantly the Court's power to give an effective judgment which is the key.

\subsection{The test for jurisdiction}

In Ewing McDonald \& Co Ltd v M \& M Products $C o^{45}$ the Appellate Division, as it was then known, defined the term jurisdiction as 'the power vested in a Court by law to adjudicate upon, determine and dispose of a matter.' In the determination of jurisdiction, the requirement of legality is therefore the overriding consideration. As Ngcobo $\mathrm{J}$ correctly noted in $S v$ Jordan, ${ }^{46}$ the Constitution is concerned with legality and not desirability. Furthermore, as Professor Theophilopoulos has quite correctly observed, jurisdiction is predicated on the twin pillars of the court's capacity to take cognizance of a case, to hear it, to give judgment and to enforce its decision. ${ }^{47}$ Further, it is the power to give an effective judgment and not merely power over the defendant which is the test of jurisdiction. ${ }^{48}$ To determine if the court is able to render an effective judgment is thus a matter of common sense.

It is convenient to pause for a moment to examine if the CCMA or the Labour Court was able to render an effective judgment in this matter. Section 193(1) of the LRA provides for reinstatement as the primary remedy against a substantively unfair dismissal. ${ }^{49}$ This remedy is to be preferred against any other remedies unless there are compelling reasons why compensation should be more appropriate in the circumstances. Furthermore, the use of the peremptory word 'must' in subsection (2)

\footnotetext{
Kylie v CCMA 200829 ILJ 1918 (LC) paras 28-37.

Ewing McDonald \& Co Ltd v M \& M Products Co 19911 SA 252 (A) 256G.

$S v$ Jordan 20026 SA 642 (CC) para 30. See also Makhanya $v$ University of Zululand 20101 SA 62 (SCA) 70 para 22.

Theophilopoulos 2010 Stell LR 132.

Pistorius Jurisdiction 4.

That section provides as follows: "If the Labour Court or an arbitrator appointed in terms of this Act finds that a dismissal is unfair, the court or the arbitrator may- (a) order the employer to reinstate the employee from any date not earlier than the date of dismissal; (b) order the employer to re-employ the employee, either in the work in which the employee was employed before the dismissal or in other reasonably suitable work on any terms and from any date not earlier than the date of dismissal; or (c) order the employer to pay compensation to the employee."
} 
indicates that the onus rests on the employer to provide compelling reasons why reinstatement should not be ordered. ${ }^{50}$

In considering the question of appropriate relief, the Court acknowledged the possible difficulties that the CCMA or the Labour Court would be confronted with when dealing with cases such as the present one. The Court pointed out, quite correctly it is submitted, that reinstatement would not be appropriate in the circumstances of the case, because by ordering reinstatement, the CCMA or Court would manifestly be ordering for violation of the provisions of the Act. ${ }^{51}$ The Court stated emphatically thus:

... this judgment does not hold that, when a sex worker has been unfairly dismissed, first respondent or a court should or can order her reinstatement, which would manifestly be in violation of the provisions of the Act. ... Manifestly, it would be against public policy to reinstate an 'employee' such as appellant in her employ even if she has could show, on the evidence, that her dismissal was unfair. ${ }^{52}$

In a similar vein, the Court stated that:

[F]or similar reasons it may well be that compensation for a substantively unfair dismissal would be inappropriate in the present kind of case. If compensation for substantive unfairness is to be regarded as a monetary equivalent for the loss of employment, it may be, although given the precise relief sought I express no final view, that such compensation would be inappropriate in a case where the nature of the services rendered by the dismissed employee are illegal. ${ }^{53}$

What this concession boils down to is that the Court appreciated the fact that with the kind and nature of the case before it, it would be virtually impossible, sometimes, for a court or the CCMA to render an effective award or judgment. This is especially true in cases where the dispute raised by the employee is based on substantive unfairness only. It follows, as a matter of logic, therefore, that in all disputes involving sex workers as employees, and/or any other employment relationships which are

50 Subsection (2) provides that the Labour Court or the arbitrator must require the employer to reinstate or re-employ the employee unless- (a) the employee does not wish to be reinstated or re-employed; (b) the circumstances surrounding the dismissal are such that a continued employment relationship would be intolerable; (c) it is not reasonably practicable for the employer to reinstate or re-employ the employee; or (d) the dismissal is unfair only because the employer did not follow a fair procedure.

Kylie v CCMA 20104 SA 383 (LAC) para 51

Kylie v CCMA 20104 SA 383 (LAC) para 52.

Kylie v CCMA 20104 SA 383 (LAC) para 53. 
characterised by an element of illegality, the courts may not be able to render effective judgment and may therefore not assume jurisdiction to resolve the dispute involved. $^{54}$

In employment relationship disputes, then, the proper approach is for the court to determine jurisdiction in terms of the LRA and the legal rules applicable to the dispute before it. In so doing the court or the CCMA would scrutinise the nature of the dispute to determine if there are any traces of illegality in the particular transaction giving rise to the dispute. This determination may, however, be effectively done after a proper examination of the true nature of the dispute has been undertaken by the court. In this regard the guidance given by the Constitutional Court in NUMSA $v$ Bader Bop (Pty) Ltd ${ }^{55}$ is apposite: it is the duty of a court to ascertain the true nature of the dispute between the parties. In ascertaining the real dispute a court must look at the substance of the dispute and not at the form in which it is presented. ${ }^{56}$ The true nature of the dispute, or the real issue, in this matter (Kylie) was not at all about the protection of the constitutional right to fair labour practice (section 23(1)), as presented by the employee, but the jurisdiction of the CCMA to deal with that kind of dispute.

It is submitted that had the Court followed the above approach, it would undoubtedly have been impossible for it to come to the conclusion it reached.

\subsection{The relevance and appropriateness of section 23 to the case}

As argued above, the Court's approach in deciding this matter, specifically its heavy reliance on section 23 of the Constitution, was unnecessary. It is submitted that, by adopting the approach which it did, the Court seemingly lost sight of the purpose of the LRA, namely to be the exclusive statute regulating labour relations. ${ }^{57}$ In NAPTOSA v Minister of Education, Western Cape ${ }^{58}$ the Court held that a litigant may not bypass the provisions of the LRA and rely directly on the Constitution without

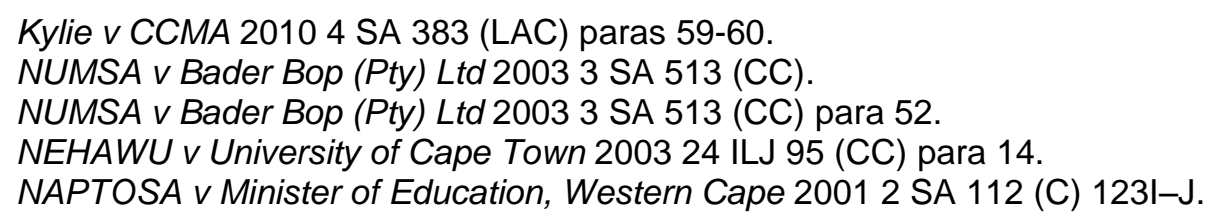


challenging the provisions of the LRA on constitutional grounds. A similar view was taken by Ngcobo $\mathrm{J}$ in Minister of Health $v$ New Clicks South Africa (Pty) (Treatment Action as Amici Curiae). ${ }^{59}$

In its approach, the Labour Appeal Court seems to have ignored the fact that the employee bypassed the relevant provisions of the LRA and relied directly on the Constitution to seek a remedy. The employee did not challenge any specific provision of the LRA on constitutional grounds. Instead, she contended that the approach adopted by the Labour Court was wrong because that approach effectively excluded her from enjoying her constitutionally entrenched right to fair labour practices. ${ }^{60}$ But does the LRA provide no remedy? Clearly the employee is covered by the definition of 'employee' in the LRA. It is trite that the LRA is aimed to be a one-stop shop dispute resolution structure in the employment sphere, ${ }^{61}$ and that the Labour Courts and the Labour Appeal Court derive their jurisdiction from it. ${ }^{62}$ In its approach, therefore, the Court should have started with the LRA, and not the Constitution, in deciding the question of jurisdiction in this matter. It goes without saying then that the Court was clearly misguided in its reliance on section 23 of the Constitution in deciding the matter. This conclusion, though, does not in any way suggest that the Court, in adjudicating any particular employment dispute, may not rely on the Constitution to determine the dispute. What is in fact contended is that section 23(1) may not exclusively be invoked to determine jurisdiction. Other factors, such as the possibility of rendering an effective judgment, as argued above, should also be considered.

Based on the abovementioned authority, ${ }^{63}$ it is clear that the Court's invocation of section 23 of the Constitution at the jurisdictional stage was inappropriate. The employee's challenge was not raised against a provision of the LRA. If there were any legal rule which had the effect of (unconstitutionally) ousting the CCMA or

59 Minister of Health $v$ New Clicks South Africa (Pty) Ltd (Treatment Action Campaign as Amici Curiae) 20062 SA 311 (CC); see also SANDU v Minister of Defence 20075 SA 400 (CC) 420 para 51.

60 The employee's argument appears in the judgment as recounted by the court in paras 14-15.

Chirwa v Transnet Ltd 20084 SA 367 (CC) para 54.

NEHAWU v University of Cape Town 200324 ILJ 95 (CC) para 30.

NEHAWU v University of Cape Town 200324 ILJ 95 (CC) paras 14 and 30; NAPTOSA $v$ Minister of Education, Western Cape 20012 SA 112 (C) 123I-J; Chirwa v Transnet Ltd 20084 SA 367 (CC) para 54. 
Court's jurisdiction to the detriment of the employee, such a legal rule would, obviously, be tested against the LRA. For that purpose section $210^{64}$ of the LRA would have been used to safeguard the LRA against any undue intrusion.

The next issue to be considered, and this is quite critical in this analysis, is the implication of the Court's judgment for the Constitution and for the future of labour litigation in general.

\subsection{May a constitutional provision be interpreted as conferring on the court the jurisdiction to enforce illegal transactions?}

It is important first to set out the legal principles relating to illegal contracts in our law. It is a fundamental principle of our law that any act done contrary to the direct prohibition of the law is void and of no effect. ${ }^{65}$ This principle is applied by courts in all legal systems based on the rule of law and is a necessary incident of the rule of law in the same way as the doctrine of legality is. ${ }^{66}$ Accordingly, if a contract is illegal, the courts regard the contract as void and therefore unenforceable. ${ }^{67}$

In the course of its assessment of the legal issues, the Court accepted the employee's argument that the illegal activity of a sex worker does not per se prevent the latter from enjoying a range of constitutional rights. ${ }^{68}$ In support of this view the Court made reference to the minority judgment of O'Regan and Sachs $\mathrm{JJ}$ in $S \mathrm{v}$ Jordan $^{69}$ where it was held, in part:

[T] he very character of the work they undertake devalues the respect that the Constitution regards as inherent in the human body. This is not to say that as prostitutes they are stripped of the right to be treated with respect by law enforcement officers. All arrested and accused persons must be treated with dignity by the police. But any invasion of dignity, going beyond that ordinarily implied by an arrest or charge that occurs in the course of arrest of incarceration cannot be

64 That section provides that "[i]f any conflict, relating to the matters dealt with in this Act, arises between this Act and the provisions of any other law save the Constitution or any Act expressly amending this Act , the provisions of this Act will prevail".

65 Schierhout $v$ Minister of Justice 1926 AD 99 109, as quoted by Cheadle $\mathrm{J}$ in Kylie v CCMA 2008 29 ILJ 1918 (LC) para 28.

$66 \quad$ Kylie v CCMA 200829 ILJ 1918 (LC) para 30.

67 Kylie v CCMA 200829 ILJ 1918 (LC) para 32.

68 Kylie v CCMA 20104 SA 383 (LAC) para 20.

69 S v Jordan 20026 SA 642 (CC). 
attributed to section $20(1 \mathrm{~A})(\mathrm{a})$ but rather to the manner in which it is being enforced. The remedy is not to strike down the law but to require that it be applied in a constitutional manner. Neither are prostitutes stripped of the right to be treated with dignity by their customers. The fact that a client pays for sexual services does not afford the client unlimited license to infringe the dignity of the prostitute.

It submitted that the Court's reference to the abovementioned authority was not at all helpful to its reasoning. Firstly, as correctly categorised by the majority judgment in $S$ $v$ Jordan, ${ }^{70}$ per $\mathrm{Ngcobo} \mathrm{J}$, the case was concerned with the commercial exploitation of sex and not an infringement of dignity nor unfair discrimination, ${ }^{71}$ nor in the present context, a dispute about the right to fair labour practices. Secondly, many of the views expressed by the minority judgment were rejected in the majority judgment. $^{72}$ In support of the reasoning based on the sex worker's right to dignity, the Court recorded its observation that within the South African context many sex workers are particularly vulnerable and are exposed to exploitation and vicious abuse, ${ }^{73}$ and for that reason are entitled to some constitutional protection designed to protect their dignity, which protection by extension has now been operationalised in the LRA. ${ }^{74}$ It is submitted that this line of reasoning is, with respect, equally unsound. The reasoning is not supported by any relevant legal authority and appears to be more inventive than considerate of the current legally relevant authority. ${ }^{75}$ That a sex worker forms part of a vulnerable class does not mean that the court is bound to assume jurisdiction simply because of that fact. What if the particular sex worker is one of those sex workers in the plush suburbs of Johannesburg who charges R20 000 a night and does not need the protection? In other words, is it necessary to conceive of the litigant as a victim in order to want to come to her aid? ${ }^{76}$ By the same token, the fact that a person has a right to life or to be treated with dignity does not mean that the courts should come to his or her assistance if he or she surrenders

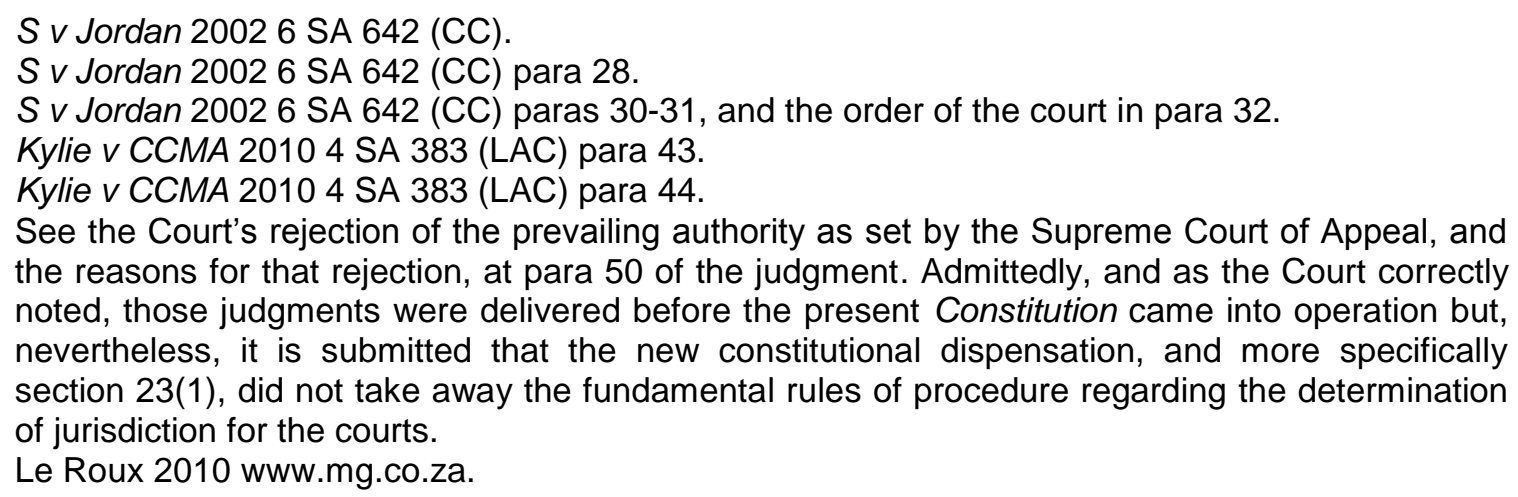
the reasons for that rejection, at para 50 of the judgment. Admittedly, and as the Court correctly noted, those judgments were delivered before the present Constitution came into operation but, nevertheless, it is submitted that the new constitutional dispensation, and more specifically section 23(1), did not take away the fundamental rules of procedure regarding the determination of jurisdiction for the courts.

Le Roux 2010 www.mg.co.za. 
such rights by engaging in acts which conflict with the law. To hold otherwise would certainly lead to absurdity.

Without overstating the fact, this case hinged purely on jurisdiction. The key question in this analysis therefore is simply if the common law requirement of legality in the determination of a court's jurisdiction in employment disputes indeed offends against the provisions of the Constitution, specifically the right to fair labour practices (section 23). Should it be accepted also that the Constitution, as the supreme law of the land, confers in general jurisdiction on the courts and tribunals to adjudicate matters and disputes flowing from illegal activities? Clearly, the answer cannot be anything close to affirmative. It is to be hoped that this matter will attract the attention of a superior court soon, and that a definitive pronouncement will be made.

\section{$5 \quad$ The significance of Kylie v CCMA 20104 SA 383 (LAC)}

Sex work is illegal in South Africa, yet it exists. It is not difficult to imagine how many cases would flow into the labour litigation mainstream following this judgment, the nature of the cases that the CCMA Commissioners are likely to be confronted with on a daily basis, and the reaction of the Commissioners upon receipt of such cases. One can think of quite a number of examples of cases other than those involving sex workers which the CCMA Commissioners and the South African community at large would frown upon, or even hate to think of them being dealt with by the legitimate legal structures of government.

The following two examples can best illustrate this problem: think of a paid assassin whose employment (which is to murder other people for reward) has been terminated, who then approaches the CCMA to claim unfair dismissal. Should the CCMA really set up a conciliation and subsequently arbitration hearings for such a dispute? Another example one can think of is that of a gambler who knowingly engages in illegal gambling activities as an employee to promote gambling against the relevant legislation. In the case of a dismissal or unfair labour practice dispute ensuing between such an employee and his or her employer, should the CCMA nevertheless assume jurisdiction to resolve the dispute because the judgment in this 
matter regards such a person as an employee for the purposes of the Constitution? It is submitted that the implications will be quite undesirable and surely, it is submitted, would not have been what the Court intended in its judgment.

Before concluding, there is one other issue regarding the Court's comment on the future adjudication of cases involving employment relationships which are in breach of legislation which requires a quick examination. The Court stated that "cases involving employment relationships which are in breach of legislation, such as the present dispute, should proceed through the constitutional threshold but not all will enjoy the defining weight of public policy, as set out, so as to justify the granting of a remedy". 77

It is doubtful if the court really appreciated the implications of this finding. On proper interpretation, this statement could mean that all those employees who, but for illegality, are employees in terms of section $213^{78}$ of the LRA may rely not on the LRA to seek a remedy in the CCMA or Labour Court, but directly on the Constitution. The implications are that such employees would be excluded from the application of the LRA, just as the members of the South African National Defence Force, the National intelligence Agency and the Secret Service are. ${ }^{79}$ If this is indeed what the above statement of the Court intended to convey, then the Court's order, directing that the CCMA has jurisdiction to resolve the dispute in this case, was absurd. Otherwise the Court should not have ruled that the CCMA has jurisdiction, because the CCMA is not empowered to resolve disputes which flow directly from challenges based on a constitutional provision but enforces the LRA strictly. Only the High Court, concurrently with the Labour Court, is empowered to adjudicate disputes in respect of alleged or threatened violation of any fundamental right entrenched in the Bill of Rights, including those arising from employment and from labour relations. ${ }^{80}$ Even if the CCMA were to assume jurisdiction, it is submitted that it would be

Kylie v CCMA 20104 SA 383 (LAC) para 57.

78 Section 213 of the LRA defines an employee as any person, excluding an independent contractor, who works for another person or for the State and who receives, or is entitled to receive, any remuneration.

79 Section 2 of the LRA expressly excludes from its application the members of the South African National Defence Force, the National Intelligence Agency, and the South African Secret Services.

80 Section 157(2) of the LRA. 
prevented from resolving unfair dismissal disputes based on the constitutional provision without reference to the LRA, because the concept of unfair labour practice, as conceptualised in section 23 of the Constitution, is not defined in the Constitution but only in the LRA. In any event, the definition of an unfair labour practice in the LRA does not include unfair dismissal. ${ }^{81}$ Either way, the CCMA would still decline jurisdiction because it would not be able to render an effective award. So, to make sense of the Court's judgment in this matter appears to be quite a daunting task.

\section{Conclusion}

In the above analysis an attempt has been made to show that the approach adopted by the Court in deciding the case is unsupportive of legality. For that reason, it is argued, the judgment is problematic. What emerges from the analysis is that the Court was apparently not interested in the public policy issues which the facts of the case revealed, nor was it concerned with the implications of the judgment on effective labour litigation or the credibility of our Constitution in general. Furthermore, the reasoning of the Court, especially its finding on jurisdiction, is less than satisfactory. The judgment, it is submitted, will have far-reaching implication for the conduct of cases in the CCMA in general and in particular in respect of those cases which are characterised by elements of illegality. The judgment has undoubtedly triggered a new approach to constitutional labour interpretation and with the absurdity highlighted in some parts of the judgment, it will surely take a considerable time for the CCMA and other courts to get to make sense of it and to appreciate the legal force of the judgment.

81 Section 186(2) of the LRA defines Unfair Dismissal as follows: "'Unfair labour practice' means any unfair act or omission that arises between an employer and an employee involving - (a) unfair conduct by the employer relating to the promotion, demotion, probation (excluding disputes about dismissals for a reason relating to probation) or training of an employee or relating to the provision of benefits to an employee; (b) unfair suspension of an employee or any other unfair disciplinary action short of dismissal in respect of an employee; (c) a failure or refusal by an employer to reinstate or re-employ a former employee in terms of any agreement; and (d) an occupational detriment, other than dismissal, in contravention of the Protected Disclosures Act, 2000 (Act No 26 of 2000), on account of the employee having made a protected disclosure defined in that Act." 
Finally, it is submitted that this judgment is not the best of the judgments ever delivered by the Court, and unless it is overturned soon, the CCMA Commissioners will continue to adjudicate such labour disputes, albeit under a cloud of uncertainty. 


\section{Bibliography}

Pistorius Jurisdiction

Pistorius D Pollack on Jurisdiction $2^{\text {nd }}$ ed (Juta Cape Town 1993)

Theophilopoulos 2010 Stell LR

Theophilopoulos C "Arresting a foreign peregrinus: Bid industrial Holdings

(Pty) Ltd v Strang and a New Jurisdictional Lacuna" 2010 Stell LR 132-157

\section{Register of legislation}

Constitution of the Republic of South Africa, 1996

Labour Relations Act 66 of 1995

Sexual Offences Act 23 of 1957

\section{Register of court cases}

Chirwa v Transnet Ltd 20084 SA 367 (CC)

Denel (Pty) Ltd v Gerber 200526 ILJ 1256 (LAC)

Ewing McDonald \& Co Ltd v M \& M Products Co 19911 SA 252 (A)

Hannah v Government of the Republic of Namibia 20004 SA 940 (NmLC)

Kylie v CCMA 200829 ILJ 1918 (LC)

Kylie v CCMA 20104 SA 383 (LAC)

Makhanya $v$ University of Zululand 20101 SA 62 (SCA)

Minister of Health $v$ New Clicks South Africa (Pty) Ltd (Treatment Action Campaign as Amici Curiae) 20062 SA 311 (CC)

NAPTOSA v Minister of Education, Western Cape 20012 SA 112 (C)

NEHAWU v University of Cape Town 200324 ILJ 95 (CC)

NUMSA v Bader Bop (Pty) Ltd 20033 SA 513 (CC)

$S v$ Jordan 20026 SA 642 (CC)

SANDU v Minister of Defence 19994 SA 482 (CC)

SANDU v Minister of Defence 20075 SA 400 (CC)

Schierhout $v$ Minister of Justice 1926 AD 99

State Information Technology Agency (Pty) Limited v CCMA 200829 ILJ 2234 (LAC) 


\section{Register of internet resources}

Le Roux 2010 www.mg.co.za

Le Roux M 2010 'Not all Sex Workers are Victims' Mail \& Guardian 4 June 2010 www.mg.co.za/article/2010-06-04-not-all-sex-workers-are-victims [date of use 30 Aug 2010]

Kwinika 2010 nehandaradio.com

Kwinika S 2010 'Prostitutes flock to SA ahead of World Cup' Nehanda Radio:

Zimbabwe News and Internet Radio Station 13 May 2010 nehandaradio.com/2010/05/13/prostitutes-flock-to-sa-ahead-of-world-cup [date of use 31 Aug 2010]

Skoch 2010 www.globalpost.com

Skoch I 2010 'World Cup welcome: a billion condoms and 40,000 sex workers' Global Post 7 May 2010 www.globalpost.com/dispatch/sports/ 100505/world-cup-sex-workers/ [date of use 31 Aug 2010]

\section{List of abbreviations}

BCEA Basic Conditions of Employment Act

CCMA Commission for Conciliation, Mediation and Arbitration

LAC Labour Appeal Court

LC Labour Court

LRA Labour Relations Act

NEHAWU National Education Health and Allied Workers Union

NAPTOSA National Professional Teachers Organisation of South Africa

NUMSA National Union of Metalworkers of South Africa

SANDU South African National Defence Union

Stell LR Stellenbosch Law Review 